\title{
Geological record of prehistoric tsunamis in Mugi town, facing the Nankai Trough, western Japan
}

\author{
Yumi Shimada ${ }^{1,3^{*}} \mathbb{D}$, Shigehiro Fujino ${ }^{2}$, Yuki Sawai ${ }^{3}$, Koichiro Tanigawa $^{3}$, Dan Matsumoto ${ }^{3}$, Arata Momohara ${ }^{4}$, \\ Megumi Saito-Kato ${ }^{5}$, Masaki Yamada ${ }^{6}$, Eri Hirayama', Takahiro Suzuki ${ }^{1}$ and Catherine Chagué ${ }^{7}$
}

\begin{abstract}
Stratigraphic and paleontological investigations in Mugi Town, on the Pacific coast of Shikoku Island, revealed evidence of as many as five tsunami inundations from events along the Nankai Trough between 5581 and $3640 \mathrm{cal} \mathrm{yr} \mathrm{BP.} \mathrm{Nine}$ event deposits (E1-E9) were identified in cores ranging in length from 2 to $6 \mathrm{~m}$, consisting of sandy and gravelly layers interbedded with organic-rich mud. Sedimentary structures in the event deposits observed by computed tomography included normal grading and sharp lower stratigraphic contacts. Event deposits E3, E6, E7, and E8 contained mainly brackish-marine diatom species, suggesting that they had been deposited during inundation by seawater. In addition, fossil diatom assemblages were markedly different above and below event deposits E3, E4, E6, and E8. For example, assemblages below event deposit E6 were dominated by a freshwater species (Ulnaria acus), whereas assemblages above it were predominantly brackish-marine (Diploneis smithii, Fallacia forcipata, and Fallacia tenera). We attributed these changes to the increase of marine influence due to coastal subsidence associated with subduction-zone earthquakes, as documented in the 1946 Showa-Nankai earthquakes. We conclude that event deposits E3, E6, and E8 and perhaps E4 and E7 were deposited by tsunamis generated by subduction zone earthquakes along the Nankai Trough. The ages of these event deposits, as constrained by ten radiocarbon ages, suggest that some of the tsunamis that impacted Mugi Town were correlated with those reported elsewhere along the Nankai Trough, thereby complementing the existing but still incomplete geological record for these events.
\end{abstract}

Keywords: Tsunami deposits, Subduction zone earthquake, Environmental change, Coastal deformation, Diatom, Nankai Trough, Tokushima Prefecture

\section{Introduction}

The Pacific coast of Japan has been repeatedly affected by subduction zone earthquakes and tsunamis. Long-term forecasts of subduction zone earthquakes are calculated by the Japanese government on the basis of earthquake histories (The Headquarters for Earthquake Research Promotion 2013). The long-term forecasts for the Nankai Trough region in western Japan relied mainly on historical documents from the last 1300 years (The Headquarters for Earthquake Research Promotion 2001), although there

\footnotetext{
* Correspondence: yumi-shimada@geol.tsukuba.ac.jp

${ }^{1}$ Graduate School of Life and Environmental Sciences, University of Tsukuba,

1-1-1 Tennodai, Tsukuba, Ibaraki 305-8572, Japan

${ }^{3}$ Geological Survey of Japan, National Institute of Advanced Industrial

Science and Technology (AIST), 1-1-1-C7 Higashi, Tsukuba, Ibaraki 305-8567,

Japan

Full list of author information is available at the end of the article
}

were a few reports on geological records of prehistoric tsunamis (Okamura et al. 2000). After 2001, geological studies discovered evidence of unusually large prehistoric tsunamis in other subduction zones, including Thailand (Jankaew et al. 2008), Sumatra (Monecke et al. 2008), and Hokkaido (Nanayama et al. 2003; Sawai et al. 2009a). Along the Japan Trench, a tsunami deposit associated with the 869 CE Jogan earthquake was identified (e.g., Abe et al. 1990; Minoura and Nakaya 1991; Minoura et al. 2001) that later was recognized as a predecessor of the 2011 Tohoku earthquake and tsunami (Sawai et al. 2012). The most recent evaluation for the Nankai Trough region sought to incorporate geological records of prehistoric earthquakes (The Headquarters for Earthquake Research Promotion 2013). However, while more than 70 recent publications have presented paleoseismological evidence 
(Garrett et al. 2016), only a few have provided the well-dated evidence needed to understand past fault behavior through regional correlations (Fujino et al. 2018; Tanigawa et al. 2018).

This study was carried out in a coastal lowland in Mugi Town, adjacent to the Nankai Trough, with the aim of identifying prehistoric tsunami deposits and estimating event ages. Our findings provide new information on the history of subduction zone earthquakes along the Nankai Trough, complementing the meager existing record.

\section{Study area}

\section{Site selection}

The study was carried out in a small and isolated freshwater wetland (about $250 \times 150 \mathrm{~m}$ ) in Mugi Town in southeastern Shikoku Island (Fig. 1). The wetland is separated from the sea by a sand barrier through which a narrow drainage channel runs (Fig. 1d). The barrier shields the wetland from waves and tidal flows that could lead to deposition of coarse marine sediments. No rivers flow into the wetland, and therefore there is no input of alluvial sediment. These topographical conditions favor the preservation and identification of tsunami deposits because only extreme high-energy events are likely to deliver sand or gravel into the wetland. Sandy and gravelly event deposits interbedded within muddy sediments are left undisturbed, making their identification easier. The wetland is surrounded by coastal hills mainly dominated by shale and sandstone (Kumon 1981; Onishi and Kimura 1995; Yamaguchi et al. 2009) of late Cretaceous to Eocene age (Suyari and Yamasaki 1987; Shibata et al. 2008). The elevation of core locations (Fig. 1d) ranges from $2.37 \mathrm{~m}$ at MG12 to $3.10 \mathrm{~m}$ at MG11 (all elevations in this paper are reported with respect to sea level at the Tokyo Peil). The present elevation of the sand barrier is approximately $4.0 \mathrm{~m}$; however, the natural elevation of the sand barrier is not known because an embankment has been constructed upon it. The site was formerly a rice paddy field, but it was abandoned about 10-15 years before the time of this study. According to the town's official history (Mugi Choshi), the wetland has been isolated from recent flooding and storm surges, but the barrier is low enough to have been overtopped by the Showa-Nankai tsunami in 1946 (wave height of $4.5 \mathrm{~m}$ in Mugi Town; Editing Committee of the History of Mugi Town 1976, Central Meteorological Observatory 1947).

\section{Historical tsunamis in Mugi town}

The last four great earthquakes along the Nankai Trough (the 1605 CE Keicho, 1707 CE Hoei, 1854 CE Ansei-Nankai, and 1946 CE Showa-Nankai earthquakes) generated tsunamis that hit Mugi Town (Editing
Committee of the History of Mugi Town 1976). The post-disaster survey report of the Showa-Nankai earthquake (Central Meteorological Observatory 1947) indicated that the tsunami inundation area included the whole study site. The Showa-Nankai earthquake also caused coastal subsidence of at least $0.3 \mathrm{~m}$ or more in this area, such that groins built to stand above spring high tides were submerged to about $0.3 \mathrm{~m}$ depth at spring tides after the earthquake (Editing Committee of the History of Tokushima Prefecture 1963). Other detailed information on damages and coastal deformation caused by these four earthquakes is summarized in Table 1.

\section{Methods/Experimental}

Sediment samples were collected at 13 locations (MG01-MG13) along 2 transects, 1 perpendicular and the other parallel to the shoreline (Fig. 1d). Samples at all sites except MG05 were obtained with a gouge auger. At MG05, sediment was sampled successively with a Handy Geoslicer (Nakata and Shimazaki 1997) from 0 to $120 \mathrm{~cm}$, a thin-wall sampler from 120 to $400 \mathrm{~cm}$, and a Russian sampler from 400 to $450 \mathrm{~cm}$ depth below the ground surface. Surface elevations of each location were obtained with a GNSS survey instrument, Leica Viva GS08 Plus GNSS receiver (Leica Geosystems).

Sedimentary structures in the MG05 samples were observed using X-ray computed tomography (LightSpeed Ultra 16, GE Healthcare Japan) at the Center for Advanced Marine Core Research, Kochi University. Cores were then split and peels were prepared using a hydrophilic glue (SAC-100) for further observation of sedimentary structures.

Subsamples for paleontological analysis were taken every centimeter from cores MG05 and MG10. Subsamples were also taken from the other cores to provide plant macrofossils for radiocarbon dating. Diatom analysis was carried out at 1-5 cm intervals in core MG05. Samples were prepared with the bleaching method proposed by Nagumo and Kobayasi (1990) and Nagumo (1995) and placed on slides for examination under an optical microscope ( $\times 600$ magnification) and a scanning electron microscope (JEOL JSM-6510). More than 200 valves were identified and counted on each slide. Diatoms were identified and paleoenvironments were assigned on the basis of standard sources (e.g., Patrick and Reimer 1966, 1975; Krammer and Lange-Bertalot 1986; Witkowski et al. 2000; Kobayasi et al. 2006; Levkov 2009).

Plant macrofossils (e.g., fruits, seeds, needles, and leaves) from core MG10 were picked out under a binocular microscope for interpretation of paleoenvironments and radiocarbon dating (Table 2). All samples were measured by accelerator mass spectrometry (AMS) at Beta Analytic. Radiocarbon ages were calibrated by using OxCal 4.3.2 software (Bronk Ramsey 2017) with 
A

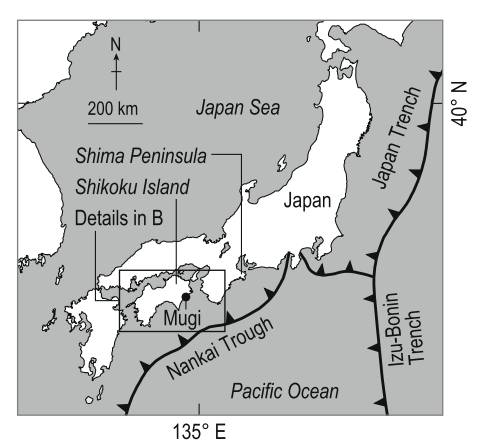

C

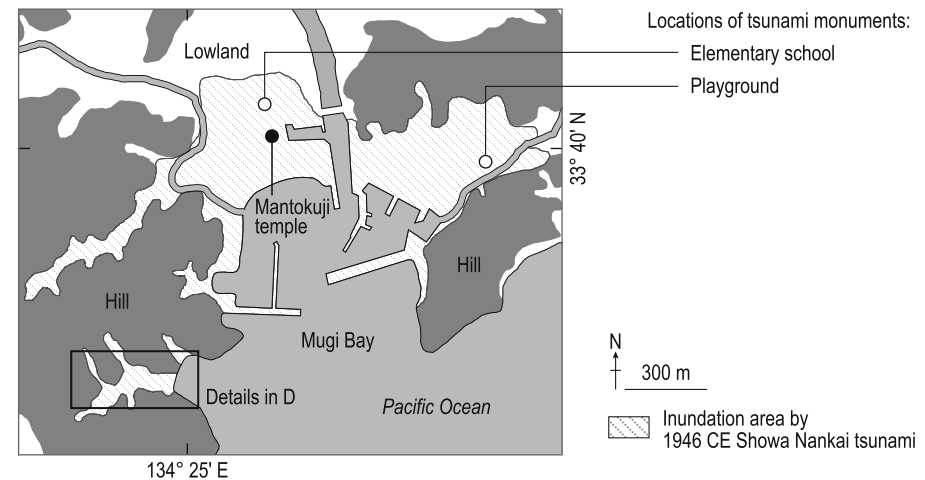

B

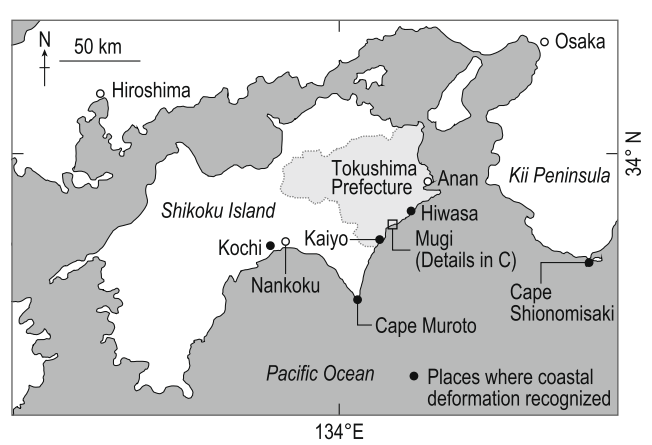

\begin{tabular}{c}
$z$ \\
$z$ \\
\hdashline \\
\hdashline
\end{tabular} 
Table 1 Information of the last four historical earthquakes and tsunamis

\begin{tabular}{|c|c|c|c|c|c|c|}
\hline $\begin{array}{l}\text { Name of } \\
\text { earthquake }\end{array}$ & Date (CE) ${ }^{a}$ & $\begin{array}{l}\text { Moment } \\
\text { magnitude (Mw) }\end{array}$ & Rupture zone ${ }^{a}$ & Coastal ${ }^{b, d}$ deformation & $\begin{array}{l}\text { Number of tsunami } \\
\text { monuments in } \\
\text { Mugi Town }\end{array}$ & $\begin{array}{l}\text { Other descriptions in } \\
\text { Mugi Town }\end{array}$ \\
\hline Keicho & 3 February 1605 & No data & $\begin{array}{l}\text { Various } \\
\text { interpretations } \\
\text { suggested }\end{array}$ & No data & No data & $\begin{array}{l}\text { Mantokuji temple was washed } \\
\text { away. }{ }^{f} \text { (The temple sat at } \\
3.5 \text { m T.P. }{ }^{9} \text { ) }\end{array}$ \\
\hline Hoei & 28 October 1707 & $8.6^{\mathrm{b}}$ & $\begin{array}{l}Z+A+B+C \\
+D(+E ?)\end{array}$ & No data & No data & $\begin{array}{l}\text { Tsunami waves ran up three } \\
\text { rivers. }{ }^{f} \text { More than } 700 \text { houses } \\
\text { were washed away and more } \\
\text { than } 100 \text { people died. }{ }^{f} \\
\text { Mantokuji temple was washed } \\
\text { away. }{ }^{f} \text { The tsunami ran up to } \\
\text { about } 1.5 \mathrm{~km} \text { on the Uchizuma } \\
\text { River. }{ }^{\mathrm{fh}}\end{array}$ \\
\hline Ansei-Nankai & 24 December1854 & $8.4^{b}$ & $Z+A+B$ & $\begin{array}{l}\text { Uplift in Cape Muroto } \\
\text { ( } 1.2 \text { m)Subsidence in } \\
\text { Kochi City (1.1 m) }\end{array}$ & $\begin{array}{l}2 \text { Playground and } \\
\text { Teba Island }\end{array}$ & $\begin{array}{l}640 \text { houses were carried away } \\
\text { and } 39 \text { people died. The } \\
\text { tsunami ran up to the steps } \\
\text { of the Mantokuji temple along } \\
\text { the Mugi River. }\end{array}$ \\
\hline Showa-Nankai & 21 December1946 & $8.0^{b}-8.3^{c}$ & $A+B$ & $\begin{array}{l}\text { Uplift in Cape } \\
\text { Shionomisaki } \\
(0.6 \mathrm{~m}) \text { Cape Muroto } \\
(0.5-0.9 \mathrm{~m}) \text { Subsidence } \\
\text { in Mugi Town (0.3 m } \\
\text { Or more) } \\
\text { Shishikui }(0.6 \mathrm{~m})\end{array}$ & $\begin{array}{l}3 \text { Two are in a } \\
\text { playground, and } \\
\text { the other is in an } \\
\text { elementary school. }\end{array}$ & $\begin{array}{l}\text { The whole study site was } \\
\text { inundated. } 151 \text { houses were } \\
\text { washed away and } 52 \text { people } \\
\text { died. The western part of Mugi } \\
\text { Bay was more strongly affected } \\
\text { than the eastern part because } \\
\text { the tsunami came from the } \\
\text { east. }\end{array}$ \\
\hline
\end{tabular}

${ }^{\mathrm{a}}$ From Sangawa (2007) and Ishibashi (2014)

brom Usami et al. (2013)

'From Tanioka and Satake (2001)

${ }^{\mathrm{d}}$ From Central Meteorological Observatory (1947)

'Teba Island is located about $4 \mathrm{~km}$ south of Mugi Bay

fFrom Editing Committee of the History of Mugi Town (1976)

${ }^{9}$ From Murakami et al. (1996)

hUchizuma River is located about $1 \mathrm{~km}$ west of the study site

the diatom assemblages were dominated by brackish and marine species. Brackish planktonic species included Cyclotella atomus var. gracilis and Thalassiosira lacustris. Among the benthic diatoms, brackish-marine species such as Amphora coffeaeformis, Amphora pseudoholsatica, Diploneis smithii, Diploneis suborbicularis, Fallacia forcipata, and F. tenera were most abundant. Below event deposit E6 (from - $1.25 \mathrm{~m}$ elevation to the bottom of the core), freshwater-brackish species such as Ctenophora pulchella and Cocconeis placentula were abundant. Freshwater species such as Eunotia spp. and Gomphonema spp. were found around event deposit E4. Plant macrofossils used for radiocarbon dating from core MG05 included submerged and floating-leaved plants, such as Ruppia maritima, Zannichellia palustris, Najas spp., and Potamogeton spp. (Table 2).

In the upper part of the sediments (above $\sim 0.6 \mathrm{~m}$ ), diatom assemblages were characterized by an upward decrease in brackish planktonic species and a drastic increase in the proportion of freshwater species such as Cymbella proxima, Cymbella tumida, Pinnularia spp., Stauroneis spp., and Surirella spp. In addition, the concentration of diatom fossils in the upper part, particularly at $0.8-1.1 \mathrm{~m}$ elevation (Fig. 5), was lower than that in the lower part. Samples above $0.8 \mathrm{~m}$ were characterized by mostly broken valves.

Given the sparseness of diatoms near the top of the cores, plant macrofossils were quantitatively analyzed below and above event deposit E1 at site MG10 (Fig. 6). Below E1, plant macrofossils were dominated by $\mathrm{Cla}$ dium chinense, a brackish emergent plant. Above E1, they included abundant emergent and wetland plants typical of a shallow freshwater environment, such as Persicaria pubescens, Eriocaulon spp., and Monochoria plantaginea.

\section{Event deposits, their ages, and diatom assemblages}

Event deposits (E1 to E9) and sedimentary structures were identified in tomographic images of core MG05 (Fig. 4), with the sedimentary characteristics of each event deposit summarized in Table 4. The event deposits were correlated across the cores based on their elevations, sedimentary features, and radiocarbon ages from plant macrofossils below and above the event deposits (Table 2). Ages from below event deposits were interpreted as limiting maximum ages, and ages from above them were interpreted as limiting minimum ages. For example, a radiocarbon age from unidentified leaves 
Table 2 Radiocarbon ages from Mugi Town

\begin{tabular}{|c|c|c|c|c|c|c|}
\hline$\overline{\text { No. }}$ & Site & $\begin{array}{l}\text { Elevation }(\mathrm{m}, \\
\text { T.P.) }\end{array}$ & $\begin{array}{l}\text { Conventional age } \\
\left({ }^{14} \mathrm{C} \text { yr BP }\right)\end{array}$ & $\begin{array}{l}\text { Calibrated age } 2 \sigma \text { range } \\
\text { (cal yr BP) }\end{array}$ & Material & $\begin{array}{l}\text { Lab no. } \\
\text { (Beta-) }\end{array}$ \\
\hline 1 & MG01 & 0.24 to 0.21 & $1940 \pm 30 \mathrm{BP}$ & $1970-1820$ & Needles & 465345 \\
\hline 2 & MG03 & 0.26 to 0.23 & $3460 \pm 30 \mathrm{BP}$ & $3831-3642$ & Leaf & 465341 \\
\hline 3 & MG03 & $\begin{array}{l}-0.03 \text { to }- \\
0.06\end{array}$ & $3760 \pm 30 \mathrm{BP}$ & 4237-3994 & Needles, Leaves, and Najas spp. \& unidentified taxa & 483201 \\
\hline 4 & MG03 & $\begin{array}{l}-2.63 \text { to }- \\
2.66\end{array}$ & $6000 \pm 30 \mathrm{BP}$ & $6931-6750$ & Ruppia maritima & 465342 \\
\hline 5 & MG05 & 1.65 to 1.64 & $1660 \pm 30 \mathrm{BP}$ & $1690-1421$ & Cladium chinense & 473445 \\
\hline 6 & MG05 & 1.24 to 1.21 & $2340 \pm 30 \mathrm{BP}$ & $2457-2316$ & Seeds & 503500 \\
\hline 7 & MG05 & 1.15 to 1.14 & $2740 \pm 30 \mathrm{BP}$ & $2920-2765$ & Cladium chinense & 473446 \\
\hline 8 & MG05 & 0.64 to 0.63 & $3340 \pm 30 \mathrm{BP}$ & $3678-3480$ & Cladium chinense & 474818 \\
\hline 9 & MG05 & $\begin{array}{l}-0.15 \text { to }- \\
0.16\end{array}$ & $3680 \pm 30 \mathrm{BP}$ & 4139-3914 & Leaves & 474369 \\
\hline 10 & MG05 & $\begin{array}{l}-0.68 \text { to }- \\
0.69\end{array}$ & $4030 \pm 30 \mathrm{BP}$ & $4572-4422$ & Needles & 473447 \\
\hline 11 & MG05 & $\begin{array}{l}-0.72 \text { to }- \\
0.73\end{array}$ & $4380 \pm 30 \mathrm{BP}$ & $5040-4863$ & Najas spp. & 474796 \\
\hline 12 & MG05 & $\begin{array}{l}-0.86 \text { to }- \\
0.87\end{array}$ & $4170 \pm 30 \mathrm{BP}$ & $4831-4585$ & Leaves & 473449 \\
\hline 13 & MG05 & $\begin{array}{l}-0.92 \text { to }- \\
0.93\end{array}$ & $4260 \pm 30 \mathrm{BP}$ & $4870-4711$ & Leaf & 474370 \\
\hline 14 & MG05 & $\begin{array}{l}-1.28 \text { to }- \\
1.29\end{array}$ & $4750 \pm 30 \mathrm{BP}$ & $5586-5331$ & Zannichellia palustris & 473450 \\
\hline 15 & MG05 & $\begin{array}{l}-1.79 \text { to }- \\
1.80\end{array}$ & $4780 \pm 30 \mathrm{BP}$ & $5590-5468$ & Ruppia maritima and Zannichellia palustris & 473451 \\
\hline 16 & MG06 & 0.99 to 0.97 & $2890 \pm 30 \mathrm{BP}$ & $3145-2928$ & Cladium chinense & 481643 \\
\hline 17 & MG06 & $\begin{array}{l}-0.83 \text { to }- \\
0.89\end{array}$ & $4140 \pm 30 \mathrm{BP}$ & $4824-4571$ & $\begin{array}{l}\text { Moss stems, Najas spp., Zannichellia palustris and un } \\
\text { identified taxa }\end{array}$ & 483425 \\
\hline 18 & MG06 & $\begin{array}{l}-1.76 \text { to }- \\
1.79\end{array}$ & $4470 \pm 30 \mathrm{BP}$ & $5289-4976$ & Zannichellia palustris & 482828 \\
\hline 19 & MG06 & $\begin{array}{l}-2.88 \text { to }- \\
2.91\end{array}$ & $5450 \pm 30 \mathrm{BP}$ & $6301-6205$ & Najas spp., Zannichellia palustris and unidentified taxa & 483202 \\
\hline 20 & MG08 & 1.06 to 1.03 & $2610 \pm 30 \mathrm{BP}$ & $2776-2721$ & Cladium chinense & 465343 \\
\hline 21 & MG08 & $\begin{array}{l}-0.64 \text { to }- \\
0.67\end{array}$ & $4020 \pm 50 \mathrm{BP}$ & $4570-4421$ & Leaf & 465344 \\
\hline 22 & MG08 & $\begin{array}{l}-2.00 \text { to }- \\
2.03\end{array}$ & $4740 \pm 50 \mathrm{BP}$ & $5589-5326$ & $\begin{array}{l}\text { Najas spp., Ruppia maritima,Zannichellia palustris and } \\
\text { unidentified taxa }\end{array}$ & 483,427 \\
\hline 23 & MG10 & 1.48 to 1.46 & $2280 \pm 30 \mathrm{BP}$ & $2353-2161$ & Needles & 503498 \\
\hline 24 & MG10 & 1.29 to 1.27 & $2870 \pm 30 \mathrm{BP}$ & $3077-2881$ & Cladium chinense & 503499 \\
\hline 25 & MG10 & $\begin{array}{l}-0.39 \text { to }- \\
0.42\end{array}$ & $3570 \pm 30 \mathrm{BP}$ & $3972-3731$ & Cladium chinense & 483203 \\
\hline 26 & MG10 & $\begin{array}{l}-0.75 \text { to }- \\
0.78\end{array}$ & $5010 \pm 30 \mathrm{BP}$ & $5892-5656$ & Leaves, Najas spp. and unidentified taxa & 483426 \\
\hline 27 & MG10 & $\begin{array}{l}-0.66 \text { to }- \\
0.69\end{array}$ & $5780 \pm 30 \mathrm{BP}$ & $6657-6500$ & $\begin{array}{l}\text { Zannichellia palustrisRuppia maritima, and unidentified } \\
\text { taxa }\end{array}$ & 483204 \\
\hline 28 & MG13 & 0.99 to 0.97 & $2720 \pm 30 \mathrm{BP}$ & $2868-2761$ & Cladium chinense & 481644 \\
\hline 29 & MG13 & $\begin{array}{l}-2.68 \text { to }- \\
2.71\end{array}$ & $4890 \pm 30 \mathrm{BP}$ & $5662-5587$ & Najas spp., Zannichellia palustris and unidentified taxa & 482824 \\
\hline
\end{tabular}


Table 3 Depositional ages of event deposits at MG05

\begin{tabular}{|c|c|c|c|c|c|}
\hline Core location & Name of event & Age (cal yr BP, $1 \sigma$ range, 68.2\%) & Age (cal yr BP, 20 range, 95.4\%) & $\begin{array}{l}\text { Maximum conventional } \\
\text { age nos. in Table } 2\end{array}$ & $\begin{array}{l}\text { Minimum conventional } \\
\text { age nos. in Table } 2\end{array}$ \\
\hline MG05 & E1 & $2775-2451$ & $2826-2350$ & 7,8 & 5,6 \\
\hline MG05 & E2 & $3813-3577$ & 3954-3514 & 9,10 & 7,8 \\
\hline MG05 & E3 & $4030-3789$ & $4073-3640$ & 9,10 & 7,8 \\
\hline MG05 & E4 & $4656-4503$ & $4730-4452$ & 12 & 9,10 \\
\hline MG05 & E5 & $4841-4738$ & $4853-4657$ & 13 & 12 \\
\hline MG05 & E6 & $5327-4878$ & $5366-4838$ & 14 & 13 \\
\hline MG05 & E7 & $5494-5349$ & $5541-5338$ & 15 & 14 \\
\hline MG05 & E8 & $5542-5430$ & $5581-5388$ & 15 & 14 \\
\hline MG10 & E1 & $2867-2346$ & $3009-2263$ & 24 & 23 \\
\hline
\end{tabular}

Radiocarbon ages in Table 1 were constrained by OxCal version 4.3 (Bronk Ramsey 2017) with the calibration data of IntCal13 (Reimer et al. 2013). The age estimation method is based on Lienkaemper and Bronk Ramsey (2009)

obtained below event deposit E4 represents a limiting maximum age of 4831-4585 cal yr BP (No. 12 in Table 2), whereas two ages from unidentified leaves and needles above E4 correspond to limiting minimum ages of 4139-3914 and 4572-4422 cal yr BP (Nos. 9 and 10 in Table 2).

The following subsections describe sedimentary features and diatom assemblages of the nine named deposits as well as the ages of the events responsible for the deposits as constrained by radiocarbon dating. Constrained ages are reported with their $2 \sigma$ range as given in Table 3.

\section{E1 (event deposit 1)}

Event deposit E1 consisted of medium to very coarse sand (Fig. 4a) and was found at nearly all locations (MG03 to MG13, Figs. 2 and 3). Diatom assemblages were very sparse and mainly dominated by freshwater diatom species such as Cymbella proxima, C. tumida, Pinnularia spp., Stauroneis spp., and Surirella spp. Its depositional age was constrained at two locations by four and two radiocarbon ages, respectively (Nos. 5-8 at MG05 and Nos. 23 and 24 at MG10 in Table 2). The depositional age was $2826-2350 \mathrm{cal} \mathrm{yr}$ BP at MG05 and 3009-2263 cal yr BP at MG10 (Table 3).

\section{E2 (event deposit 2)}

Event deposit E2 consisted of poorly sorted medium or very coarse sand (Fig. 4b) and was found at sites MG03 to MG06 (Fig. 2). It contained some subangular gravel at MG05 (Fig. 4b). Benthic diatom assemblages consisted of freshwater species (e.g., Eunotia spp. and Gomphonema spp.) and brackish species (e.g., Navicula peregrinopsis), while planktonic diatoms included brackish species such

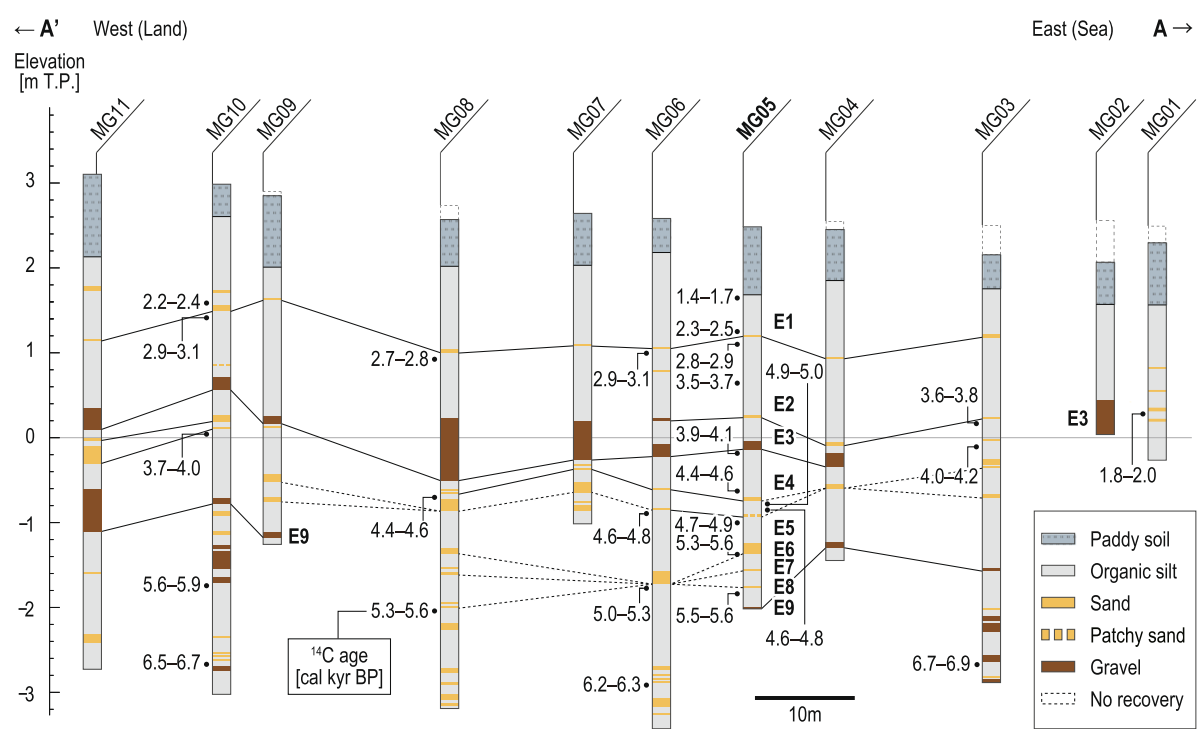

Fig. 2 Lithostratigraphy of the study site along transect A-A' in Fig. 1d. Radiocarbon ages are detailed in Table 2. The correlation of event deposits between core sites is shown by solid lines, with tentative correlations shown by dotted lines 


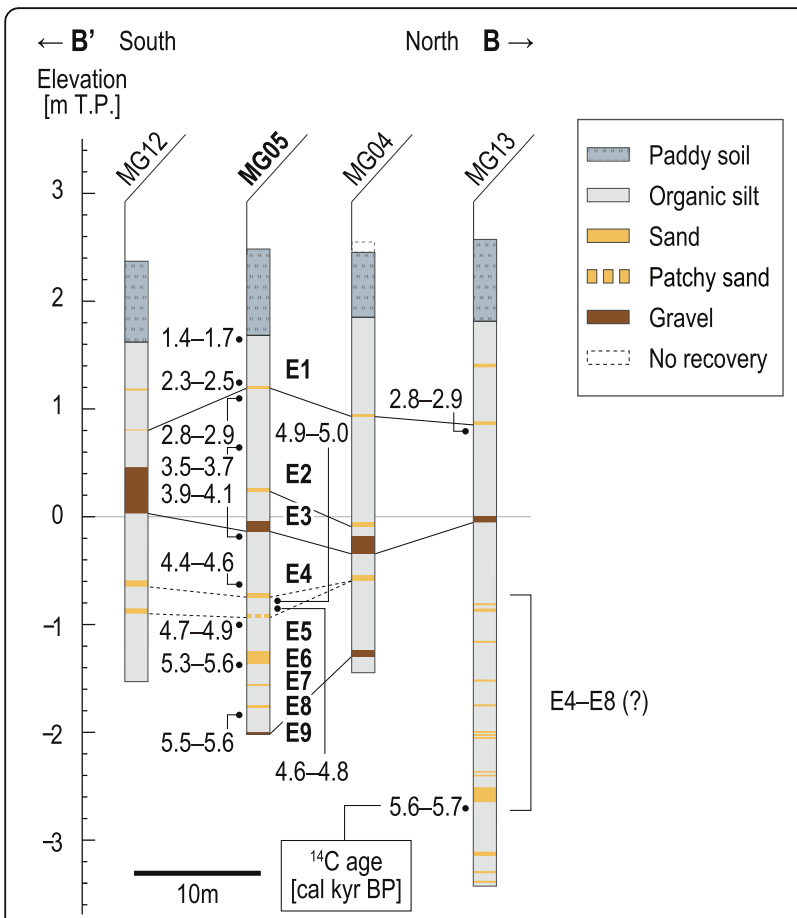

Fig. 3 Lithostratigraphy of the study site along transect B-B' in Fig. 1d. Radiocarbon ages are detailed in Table 2. The correlation of event deposits between core sites is shown by solid lines, with tentative correlations shown by dotted lines

as Thalassiosira lacustris. Its depositional age was constrained by four radiocarbon ages (Nos. 7-10 in Table 2) as 3954-3514 cal yr BP (Table 3).

\section{E3 (event deposit 3)}

Event deposit E3 consisted of poorly sorted angular gravel (Fig. 4c) and was found at MG02 and MG04 through MG13 (Figs. 2 and 3). The gravel consisted of granules and pebbles less than $3 \mathrm{~cm}$ in diameter, and the matrix was gray sandy mud. Mud clasts were observed in MG05 (Fig. 4c). The thickness of E3 varied from $4 \mathrm{~cm}$ (MG13) to $74 \mathrm{~cm}$ (MG08). It contained more specimens of brackish-marine species (e.g., Thalassiosira lacustris and Diploneis smithii) than freshwater species. Its depositional age was constrained by four radiocarbon ages (Nos. 7-10 in Table 2) as 4073-3640 cal yr. BP (Table 3).

\section{E4 (event deposit 4)}

Event deposit E4 was a single layer of well-sorted sand at six locations (MG05, MG06, and possibly MG03, MG04, MG12, and MG13; Figs. 2 and 3). The grain size ranged from very fine to very coarse sand. At MG03, MG04, MG12, and MG13, a sand layer was observed below E3 at the same elevation as E4 at MG05, but radiocarbon ages did not constrain the event ages well enough to correlate them with the event age of E4 at MG05. In addition, multiple event deposits could be correlated with E4 at MG03 and MG13. Therefore, the correlation of E4 at MG05 with the sand layers at MG03, MG04, MG12, and MG13 is tentative. A sand couplet consisting of very fine to medium sand was observed at MG07 and MG08. At MG05, this sand layer had two subunits, an upper layer of sand $5 \mathrm{~cm}$ thick and a lower layer of sand $8 \mathrm{~cm}$ thick, each with normal grading from very coarse to fine sand (Fig. 4d). Two pieces of wood were observed just above it. The sand particles were the same size in the two subunits. Diatom assemblages had a mixed composition of freshwater (Pinnularia spp.), brackish (Navicula peregrinopsis), and brackish-marine (Diploneis smithii and D. suborbicularis) species. The depositional age of E4 was constrained by three radiocarbon ages (Nos. 9, 10, and 12 in Table 2) as 4730-4452 cal yr BP (Table 3).

\section{E5 (event deposit 5)}

Event deposit E5 was found at MG05 and MG06 and possibly at seven other locations (MG03, MG04, MG07, MG08, MG09, MG12, and MG13; Figs. 2 and 3). As with $\mathrm{E} 4$, radiocarbon ages did not constrain the event ages well enough to correlate with the event age of E5 at MG05, and multiple event deposits could be correlated with E5 at MG03, MG09, and MG13. Therefore, the appearance of E5 at MG03, MG04, MG07, MG08, MG09, MG12, and MG13 is tentative. At MG05, where this unit consisted of patchy sand, it did not yield enough material for diatom analysis. Its depositional age was constrained by two radiocarbon ages (Nos. 12 and 13 in Table 2) as 48534657 cal yr BP (Table 3).

\section{E6 (event deposit 6)}

Event deposit E6, composed of poorly sorted sand with granules, was found at MG05 and possibly at MG06, MG08, and MG13 (Figs. 2 and 3). At MG06, the sand layer with a limiting maximum age of 5289-4976 cal yr BP (No. 18 in Table 2) could be correlated with E6, E7, or E8. At MG08 and MG13, multiple event deposits could be correlated with E6. Therefore, the appearance of E6 at MG06, MG08, and MG13 is tentative. Tomographic images showed that its lower stratigraphic contact was deformed due to bioturbation or the presence of a load cast (Fig. 4e). Diatom assemblages included brackish planktonic species (e.g., Cyclotella atomus var. gracilis and Thalassiosira lacustris) and brackish-marine benthic species (e.g., Amphora coffeaeformis and A. pseudoholsatica). Its depositional age was constrained by two radiocarbon ages (Nos. 13 and 14 in Table 2) as 5366-4838 cal yr BP (Table 3).

\section{E7 (event deposit 7)}

Event deposit E7 was found at MG05 and possibly at MG06, MG08, and MG13 (Figs. 2 and 3). It had three 


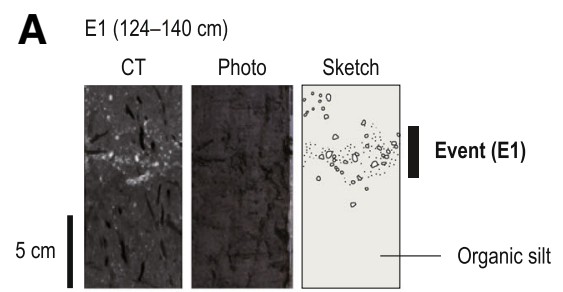

B E2 $(220-235 \mathrm{~cm})$

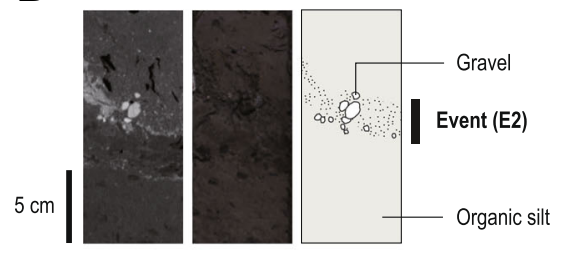

C $\quad E 3(240-275 \mathrm{~cm})$

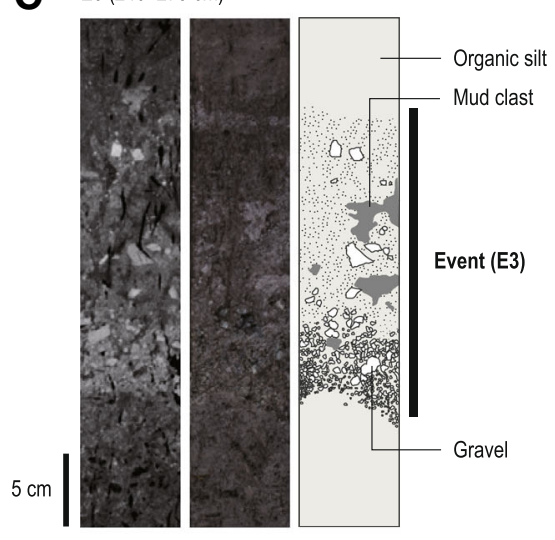

D $\mathrm{E} 4$ and $\mathrm{E} 5(310-340 \mathrm{~cm})$

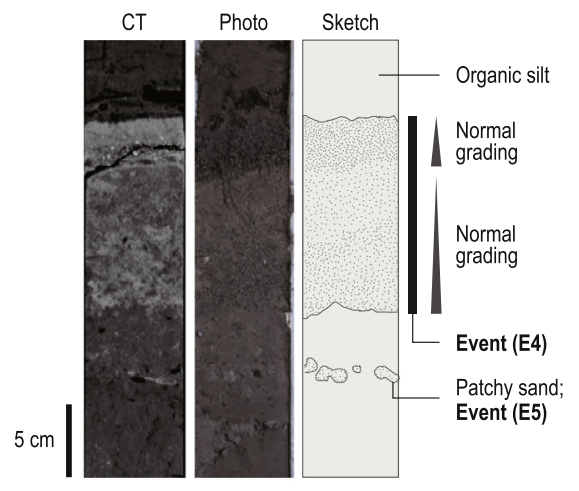

E $\quad E 6(365-385 \mathrm{~cm})$

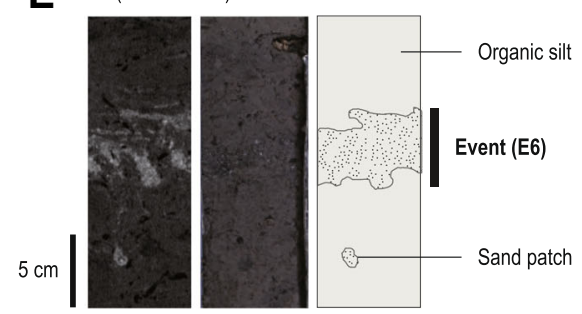

F $\quad E 7(398-410 \mathrm{~cm})$

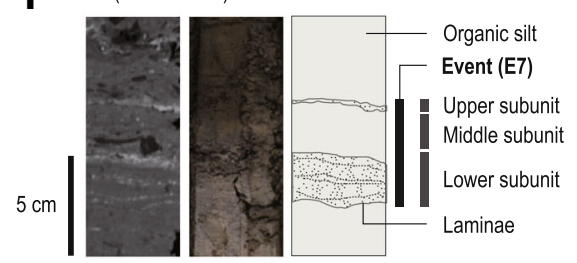

G $E 8(415-429 \mathrm{~cm})$

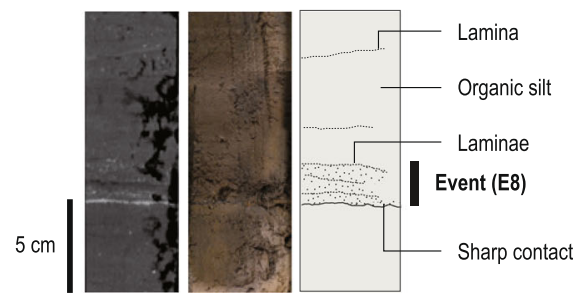

Fig. 4 Tomographic images (left), photographs (center), and interpretive sketches (right) of core MG05 showing sedimentary features of event deposits a E1, b E2, c E3, d E4 and E5, e E6, f E7, and $\mathbf{g} E 8$

subunits at MG05, an upper subunit of fine sand $0.6 \mathrm{~cm}$ thick, a middle subunit of sandy organic silt $2.0 \mathrm{~cm}$ thick, and a lower subunit of fine sand with parallel laminae $2.8 \mathrm{~cm}$ thick (Fig. 4f). Diatom assemblages were dominated by brackish-marine species Fallacia forcipata and F. tenera. Its depositional age was constrained by two radiocarbon ages (Nos. 14 and 15 in Table 2) as 5540-5338 cal yr BP (Table 3).

\section{E8 (event deposit 8)}

Event deposit E8 was found at MG05 and possibly at MG06, MG08, and MG13 (Figs. 2 and 3). It consisted of fine to medium sand at MG05 and medium to coarse sand at MG08. It displayed parallel laminae and a sharp lower stratigraphic contact at MG05 (Fig. 4g). Diatom assemblages were characterized mainly by brackish-marine species Fallacia forcipata and F. tenera and a brackish species Navicula peregrinopsis. Its depositional age was constrained by two radiocarbon ages (Nos. 14 and 15 in Table 2) as 5581-5388 cal yr BP (Table 3).

\section{E9 (event deposit 9)}

Event deposit E9, a layer of poorly sorted angular pebbles, was found at MG03, MG04, MG05, MG09, MG10, 


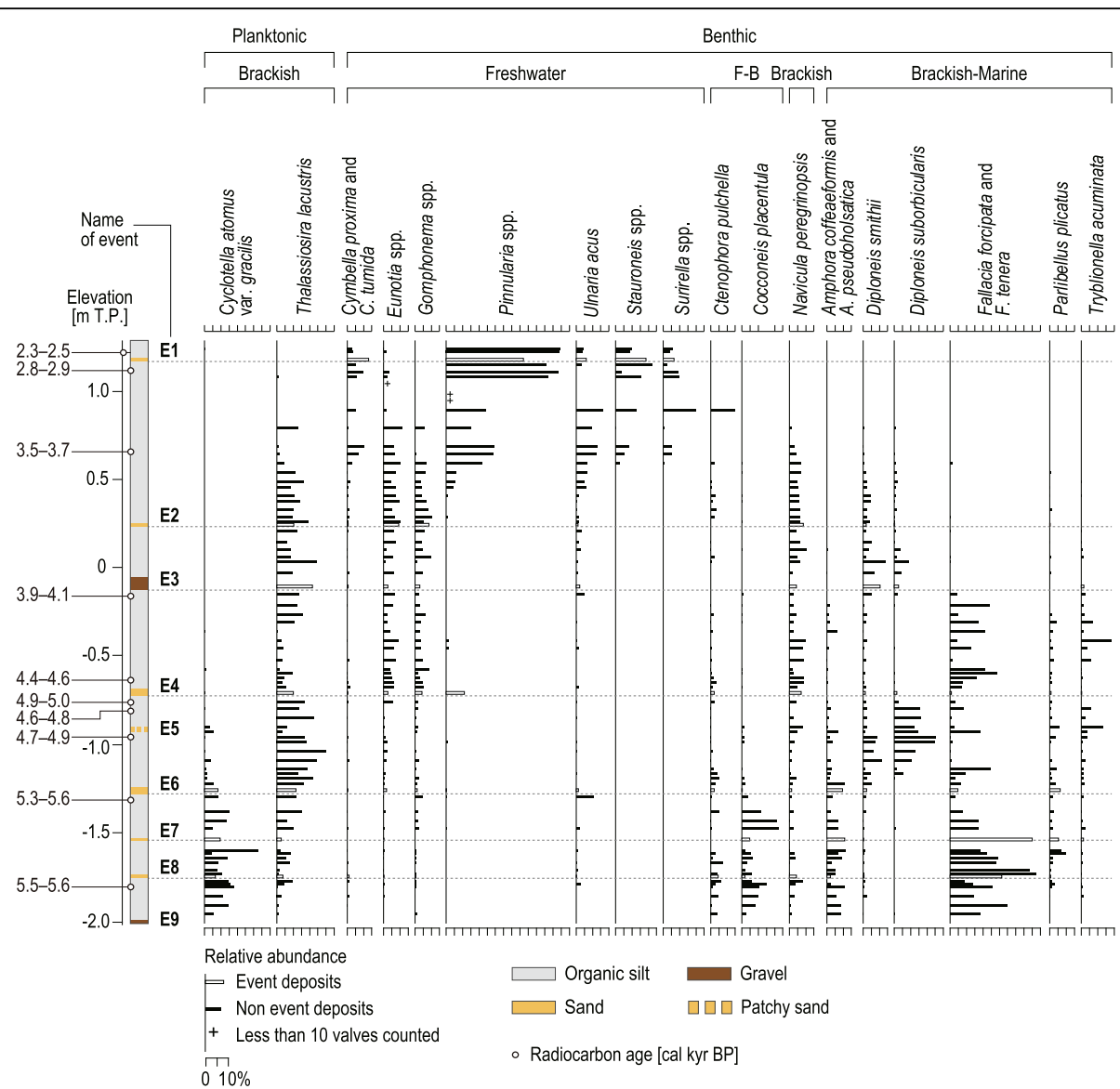

Fig. 5 Fossil diatom assemblages between - 2.02 and 1.28 m elevation (between 120 and $450 \mathrm{~cm}$ depth) in core MG05. F-B means freshwater-brackish

and MG11, but we did not find any correlated gravel layers at MG06, MG07, or MG08 (Fig. 2). No diatom analysis was possible in this material. Based on a radiocarbon age above this deposit (No. 15 in Table 2), this event is older than $5590-5468$ cal yr BP.

\section{Discussion}

Paleoecology

Changes in the diatom assemblages below and above the event deposits, as well as plant macrofossils within the organic silt, suggest that the depositional environment at

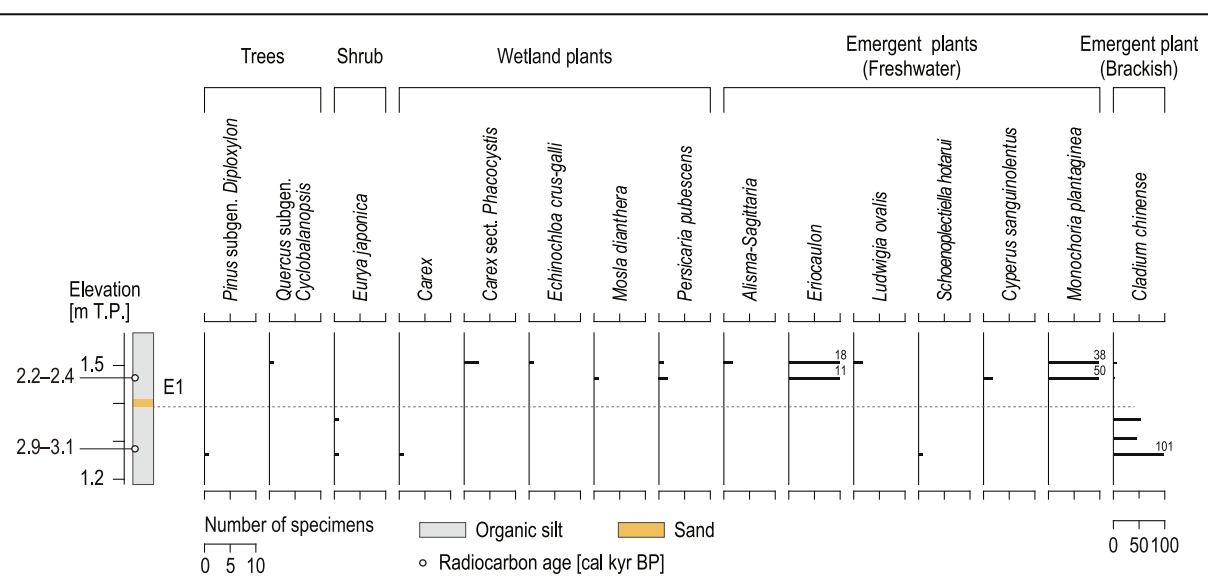

Fig. 6 Plant macrofossil assemblages between 1.18 and 1.58 m elevation in core MG10. Numbers of specimens exceeding 10 appear above the bars 
Table 4 Characteristics of event deposits at Mugi Town

\begin{tabular}{|c|c|c|c|c|c|c|c|c|c|}
\hline $\begin{array}{l}\text { Event } \\
\text { characteristics }\end{array}$ & E1 & E2 & E3 & E4 & E5 & E6 & E7 & E8 & E9 \\
\hline $\begin{array}{l}\text { Number of } \\
\text { locations observed }\end{array}$ & 11 & 4 & 11 or 12 & $4-8$ & $2-9$ & $1-4$ & $1-4$ & $1-4$ & $3-6$ \\
\hline Type of sediment & Sand & Sand & $\begin{array}{l}\text { Granule- } \\
\text { pebble }\end{array}$ & Sand & Sand & Sand & Sand & Sand & $\begin{array}{l}\text { Granule- } \\
\text { pebble }\end{array}$ \\
\hline${ }^{\mathrm{a}}$ Grading & No & No & No & $\begin{array}{l}\text { Multiple } \\
\text { normal } \\
\text { grading }\end{array}$ & No & No & No & No & No \\
\hline${ }^{\mathrm{a} M u d}$ clast & No & No & Yes & No & No & No & No & No & No \\
\hline álaminae & No & No & No & No & No & No & Parallel & Parallel & No \\
\hline aLower contact & Unclear & Unclear & Unclear & $\begin{array}{l}\text { Slightly } \\
\text { sharp }\end{array}$ & Unclear & $\begin{array}{l}\text { Sharp (deformed } \\
\text { by bioturbation } \\
\text { or load cast) }\end{array}$ & Unclear & Sharp & Not found \\
\hline aSubunits & No & No & No & byes (2) & No & No & byes (3) & No & No \\
\hline $\begin{array}{l}\text { a Other } \\
\text { sedimentological } \\
\text { characteristics }\end{array}$ & No & Poorly sorted & $\begin{array}{l}\text { Angular gravels, } \\
\text { Poorly sorted }\end{array}$ & $\begin{array}{l}\text { Sorted other } \\
\text { than MG05 }\end{array}$ & $\begin{array}{l}\text { Patchy } \\
\text { sand }\end{array}$ & Poorly sorted & No & No & $\begin{array}{l}\text { Angular gravels, } \\
\text { poorly sorted }\end{array}$ \\
\hline $\begin{array}{l}\text { aDiatoms } \\
\text { assemblages within } \\
\text { event deposits }\end{array}$ & $\begin{array}{l}\text { Freshwater } \\
\text { benthic }\end{array}$ & $\begin{array}{l}\text { Freshwater } \\
\text { benthic, brackish } \\
\text { plankton }\end{array}$ & Brackish-marine & $\begin{array}{l}\text { Mixture } \\
\text { composition }\end{array}$ & $\begin{array}{l}\text { Not } \\
\text { analyzed }\end{array}$ & Brackish-marine & $\begin{array}{l}\text { Brackish- } \\
\text { marine }\end{array}$ & $\begin{array}{l}\text { Brackish- } \\
\text { marine }\end{array}$ & Not analyzed \\
\hline
\end{tabular}

${ }^{\text {a}}$ These items are applied to MG05 core

${ }^{\mathrm{b}}$ Numbers of subunits are indicated in brackets

the study site changed from brackish to freshwater marsh during the last $\sim 5500$ years (Fig. 5 and Table 2). The samples from below $\sim 0.6 \mathrm{~m}$ elevation contained brackish planktonic diatoms that are common in brackish water bodies in Japan (Fig. 5), and plant macrofossils included hydrophytic taxa, suggesting standing water at the study site. In samples from above $\sim 0.6 \mathrm{~m}$, brackish and marine diatom species were scarce and freshwater species were dominant, indicating that the environment had changed to a freshwater marsh. Radiocarbon ages show that this change occurred just before 34803678 cal yr BP (Fig. 2 and Table 2).

Based on the change in plant macrofossils, it is likely that after about $3000 \mathrm{cal}$ yr BP, the study site was used for agriculture. Before the deposition of event deposit E1, plant macrofossils were dominated by Cladium chinense, a common species in salt marshes (Matsushita et al. 2004; Tanabe et al. 2016). However, above E1, it was replaced by Monochoria plantaginea, a well-known weed in paddy fields (Takeuchi et al. 1995) (Fig. 6). The emergence of $M$. plantaginea means that the study site changed to a terrestrial cultivated area after E1 was deposited, although it is impossible to ascertain whether the deposition of E1 was related to agricultural activity or merely coincidental with it.

\section{Origin of event deposits}

Tsunamis, flash floods, and storm surges were considered as possible causes of the event deposits based on their fossil assemblages, sedimentary features, and paleoenvironmental settings. Event deposits E5 and E9 lacked sediment for diatom analyses; therefore, their origin was not considered further in this study. However, they were most probably deposited by one of these three types of events.

Diatom assemblages provide important information to estimate the origin of event deposits (Hemphill-Haley 1996; Sawai et al. 2009b; Szczuciński et al. 2012). High-energy events such as tsunamis, flash floods, and storm surges erode and transport sediment from the surrounding area, producing sediment with a mixture of allochthonous organisms, then redeposit it into low-energy environments such as wetlands, lakes, and ponds (Sawai et al. 2008). Diatoms in these deposits are useful organisms for analyses because they have distinct assemblages that are adapted to freshwater, brackish, and marine environments.

The diatom assemblages within event deposits E3, E6, E7, and E8 had large proportions of brackish and marine species (Fig. 5). These included Fallacia forcipata and F. tenera, common in sandy beaches (Sabbe et al. 1999; Sawai et al. 2009b; Joh 2013), and Diploneis smithii, common in marine and tidal flats with high salinity (Hirose et al. 2004; Chiba and Sawai 2014). Therefore, these four deposits were not emplaced by sedimentary processes that supply terrestrial material, such as flash floods and slope collapses. Event deposit E4 contained a mixture of freshwater, brackish, and marine species, and deposits E1 and E2 contained mainly freshwater species. 
Sedimentary features in some of the event deposits were consistent with those in modern tsunami deposits. For example, the normal grading seen within event deposit E4 is also common in deposits from the 2011 Tohoku tsunami (e.g., Yamada and Fujino 2013; Matsumoto et al. 2016), the 2004 Sumatra tsunami (Choowong et al. 2008a, 2008b; Naruse et al. 2010), and the 1993 southwest Hokkaido tsunami (Nanayama and Shigeno 2006). Parallel laminae like those in deposits E7 and E8 are also documented in the 2011 Tohoku tsunami deposit (e.g., Abe et al. 2012; Nakamura et al. 2012; Matsumoto et al. 2016). However, some criteria for distinguishing tsunami deposits from deposits produced by other extreme waves are difficult to apply at the study site. For instance, tsunami deposits tend to extend over wide regions and can be found more than a kilometer inland, much farther than storm deposits (Goff et al. 2004; Morton et al. 2007). However, the core locations of the study site were all within a few tens of meters of the shoreline.

Changes in fossil diatom assemblages between samples from below and above event deposits have been used as possible indicators of synchronous seismic coastal deformation along subduction zones in Washington and Oregon (Atwater and Hemphill-Haley 1997; Atwater et al. 2005; Nelson et al. 2008), Alaska (Shennan and Hamilton 2006; Hamilton and Shennan 2005) and Hokkaido (Sawai et al. 2004). Coastal deformation suggests that the source of the event deposit is not an unusual storm surge or a distantly generated tsunami, as neither is associated with deformation. In this study, for example, the relative abundance of the brackish-marine diatom species Fallacia forcipata and F. tenera increased above event deposits E4, E6, and E8, and Diploneis smithii and D. suborbicularis, typically reported as marine diatoms in Japan (Kosugi 1988; Chiba and Sawai 2014), increased above deposits E3 and E6. These changes indicate an increased marine influence after these four events (E3, E4, E6, and E8). Interpreting them as the result of coastal subsidence is consistent with the deformation associated with historical subduction-zone earthquakes on the Nankai Trough, like the 1946 CE Showa-Nankai earthquake (Editing Committee of the History of Tokushima Prefecture 1963).

Diatom assemblages may change for reasons other than subsidence. For example, breaching and closing barriers can cause changes in salinity that may affect the composition of diatom assemblages. However, the stable dominance of planktonic diatoms (Thalassiosira lacustris and Cyclotella atomus var. gracilis) (Fig. 5) and submerged plants Najas spp. (Table 2) throughout the core suggests that an enclosed brackish water environment persisted between $\sim 5500$ and $\sim 3600$ cal yr BP without interruptions due to breaching and closing of coastal barriers. As another example, meandering channels could cause changes in diatom assemblages, but the sedimentary sequences did not exhibit any cross-stratification or reactivated surfaces of sandy sediment typically recognized in tidal inlets and deltas.

We consider event deposits E3, E6, and E8 most likely to be tsunami deposits associated with earthquakes along the Nankai Trough. These three deposits met the criteria of sedimentary characteristics, a large proportion of brackish-marine species within the event deposit, and environmental change after the event. Together with radiocarbon ages from sediments above and below these deposits, the evidence suggests that earthquakes accompanied by tsunamis occurred at least three times between 5581 and 3640 cal yr BP (Fig. 5 and Tables 2 and 3).

Evidence from deposits E4 and E7 did not strongly qualify them as tsunami deposits, but did not rule out that origin. Within E4, freshwater species were more abundant than brackish-marine species, but some modern tsunami deposits also contain mainly freshwater species (Tuttle et al. 2004; Szczuciński et al. 2012; Takashimizu et al. 2012). Deposit E7 contained abundant brackish-marine species, but there was no evidence of environmental changes after the event. Although E7 may have been the result of a storm surge or a remote tsunami, tsunamis caused by events with no coastal deformation cannot be ruled out (e.g., submarine slides and tsunami earthquakes), nor can events causing coastal deformation too subtle to lead to a change in diatom assemblages. If E4 and E7 are accepted as tsunami deposits, then at least five tsunamis may have left extensive sand sheets within our study site between 5581 and 3640 cal yr BP.

Based on the archives of local history from Anan and Hiwasa, storm inundation is unlikely to have resulted in the event deposits recorded in this study. In the southeastern part of Tokushima prefecture, at least 62 storms (described as "strong wind and rain" or "wind and rain") have affected the coastal area between 1626 and 1866 CE (Editing Committee of the History of Anan City 1995). In addition, recent records show that over 100 typhoons have struck the coast of Hiwasa between 1872 and $1955 \mathrm{CE}$ (Editing Committee of the History of Hiwasa Town 1984). If we assume that such storms have continuously occurred over hundreds of years, and that if they represented the possible origin of the event deposits in our study site, then more event deposits should exist interbedded with mud layers. We thus conclude that the five event deposits (E3, E4, E6, E7, E8) are not associated with century-scale storms.

Event deposit E2 may have been generated by an event, such as flooding, which supplied mainly terrestrial material. Consistent with this interpretation are the strong predominance of freshwater diatoms and the absence of change in diatom assemblages after the event. 
The evidence related to event deposit E1 is inconclusive. Fossil diatom assemblages below, within, and above E1 consist mainly of fragments of the freshwater genus Pinnularia (Fig. 5). However, the composition of plant macrofossils shows that the environment changed from a salt marsh to a freshwater submerged environment (Fig. 6). The appearance of the paddy field weed Monochoria plantaginea suggests that the environmental change was due to human cultivation. Another possibility is the non-tectonic regional sea-level change known as the Yayoi Regression, which affected the Japanese coast between 2000 and 3000 yr BP (e.g., Ariake Bay Research Group 1965; Sakaguchi et al. 1985; Umitsu 1991; Tanabe et al. 2016). This regression may have led to coastal emergence and desalination at the study site. Although coastal emergence due to coseismic uplift from a subduction-zone earthquake is conceivable, an uplift would be inconsistent with the subsidence documented for other prehistoric events in this study and for the 1946 CE Showa earthquake (Editing Committee of the History of Tokushima Prefecture 1963). Further study is needed to assess whether such an anomalous seismic event could have occurred in this region.

\section{Correlation of tsunami deposits with those at other sites}

The five tsunami deposits identified in Mugi Town (E3, E4, E6, E7, and E8) have the potential to be correlated with tsunami deposits and other paleoseismological evidence recognized in other regions. However, interregional correlations are hampered because of the uncertainty in radiocarbon dating, which usually has an error greater than 100 years. Tephra layers have sometimes been used as the basis for regional correlation (e.g., Nanayama et al. 2003; Sawai et al. 2012), but there are no reports of tsunami deposits associated with tephra layers in this region. Therefore, interregional correlation of tsunami events currently depends only on radiocarbon dating. Given these circumstances, this study allows possible correlations between our results and the results of previous studies that may shed light on the simultaneity and rupture zones of subduction zone earthquakes.

Tsunami deposits contemporary with those found in this study have been reported in two regions. A coastal lowland in Nankoku City, about $70 \mathrm{~km}$ west of Mugi Town in Kochi Prefecture (Fig. 1), was inundated by a tsunami between 4560 and $3730 \mathrm{cal}$ yr BP (Tanigawa et al. 2018). This age was constrained by six radiocarbon dates from plant macrofossils below and above the event deposit in two core locations and overlaps with the age of our event deposit E3 (4073-3640 cal yr BP). It also could possibly be correlated with the age of our event deposit E4 (4730-4452 cal yr BP), but the probability distributions of these two ages overlap only slightly. Thus, E3 or possibly E4 is correlated with the tsunami event in Nankoku City, although either correlation must be considered tentative given the large errors of the radiocarbon ages. However, if either event in Mugi Town is correlated with a tsunami event in Nankoku City, it suggests that a prehistoric tsunami affected a wide area along the eastern coast of Shikoku Island, rather than a more local tsunami generated by submarine mass movement (Baba et al. 2017). The oldest tsunami deposit in Nankoku City was constrained to two possible ages, 5510-4440 and 5980-4870 cal yr BP (Tanigawa et al. 2018), and thus could be correlated with any one of four event deposits in Mugi Town (E4, E6, E7, and E8). Fujino et al. (2018) described tsunami deposits on the Shima Peninsula, to the east of Mugi Town in Mie Prefecture (Fig. 1), that may be correlated with our event deposit E3, although they presented no environmental analysis of fossil species. Depositional ages of their sand $\mathrm{H}$ were 4040-3730 and 4368-3921 cal yr BP at two different locations, both of which overlap with that of our E3. In addition to these examples, Okamura and Matsuoka (2012) described sandy event deposits interbedded within lacustrine sediments in coastal areas elsewhere in Kochi, Tokushima, and Mie Prefectures. However, their depositional ages were not based on published radiocarbon ages, which prevent a detailed correlation of these event deposits (Garrett et al. 2016).

Paleoseismological evidence other than tsunami deposits has also been reported by previous studies, along with radiocarbon dating of marine carbonates. Shishikura et al. (2008) recorded two episodes of coastal uplift in the southern part of the Kii Peninsula (Fig. 1) around 4500 and $5200 \mathrm{cal}$ yr BP, based on fossil records of the sessile polychaete Pomatoleios kraussii. These episodes could be correlated with the events that led to the deposition of E4 and E6, respectively. Ikehara (1999) reported turbidites and Sakaguchi et al. (2011) reported mud-breccia units, attributable to seismic shaking, from the seafloor east of the Kii Peninsula and dated them with radiocarbon ages from foraminifers. A turbidite (turbidite 10) was bracketed by ages of $4270 \pm$ 50 and $4050 \pm 50$ yr BP (Ikehara 1999). However, our recalculation of these ages using OxCal 4.3.2 (Bronk Ramsey 2017) with Marine13 (Reimer et al. 2013) and the local marine reservoir value $\Delta R=-7 \pm 0$ (Yoneda et al. 2000) yielded a range of 3909-4513 cal yr BP, which does not match the ages of tsunami deposits in Mugi Town. A date from above the mud-breccia units provided a limiting minimum age of $3512 \pm 34$ cal yr BP (Sakaguchi et al. 2011). However, these correlations are weak given the indefiniteness of the local marine reservoir effect. Local marine reservoir values are known to vary among sites and materials (Yoneda et al. 2000, 2007; Shishikura et al. 2007; Hirabayashi et al. 2017) but there is only one published estimate of the local 
reservoir effect $(\Delta R=-7 \pm 0)$ along the Nankai Trough (Yoneda et al. 2000).

\section{Conclusions}

This study investigated the geological record of prehistoric tsunamis from Holocene coastal sediments in Mugi Town. Tsunami deposits associated with earthquakes along the Nankai Trough were identified from stratigraphic and microfossil evidence, and their depositional ages were estimated using radiocarbon ages from plant macrofossils based on Bayesian statistics. We inferred the following findings.

(1) As many as three or possibly five tsunami inundations between 5581 and $3640 \mathrm{cal} \mathrm{yr} \mathrm{BP}$ are recorded in this coastal lowland in event deposits E3, E4, E6, E7, and E8. Sedimentary features recognized in all five event deposits are consistent with modern tsunami deposits. Events E3, E6, and E8 featured both a predominance of brackish-marine diatom species within the event deposit and evidence of contemporaneous environmental changes probably associated with coastal subsidence. Event E4 featured environmental changes like those associated with events E3, E6, and E8, but had mixed freshwater, brackish, and brackish-marine diatom species. Event E7 featured abundant brackish-marine diatom species, but no evidence of environmental changes coincident with the event.

(2) Tsunami deposits E3 (4073-3640 cal yr BP), E4 (4841-4486 cal yr BP), and E6 (5364-4854 cal yr BP) can be correlated with tsunamis reported in other regions along the Nankai Trough. Further geological studies are needed in other regions to map the distributions of prehistoric tsunami deposits and coastal deformation.

(3) This site lacks evidence of tsunami inundation after event deposit E1, probably because agricultural activities continuously disturbed the surface sediments beginning about 3000 years ago. A full history of tsunami inundations at this locality will require further research in neighboring areas.

\section{Abbreviations}

cal yr BP: Calibrated radiocarbon years before the present; CE: Common era Mw: Moment magnitude

\section{Acknowledgements}

We appreciate the landowners who gave us permission to access their properties and collect samples. We also thank Yuichi Namegaya for providing information on historical documents of earthquakes and tsunamis along the Nankai Trough. The tomographic image analysis was performed under the cooperative research program of the Center for Advanced Marine Core Research, Kochi University (Accept Nos. 17A008, 17B008). We acknowledge two anonymous reviewers for their constructive comments on an earlier version of this manuscript.

\section{Funding}

This work was financially supported by the Ministry of Education, Culture, Sports and Technology of Japan as part of the Research Project for Compound Disaster Mitigation on the Great Earthquakes and Tsunamis around the Nankai Trough Region and by Japan Society for the Promotion of Science KAKENHI grant 16 K17818.

\section{Availability of data and materials}

Data sharing is not applicable to this article. Please contact the authors for data requests.

\section{Authors' contributions}

YSh, SF, YSa, KT, DM, MY, EH, TK, and CC participated in the fieldwork. YSh took core logs at 12 locations and SF took core logs at one location. YSh and MSK performed SEM imaging of diatoms. YSa and YSh identified diatoms and interpreted paleoenvironments. YSh picked out plant macrofossils for radiocarbon dating, and YSa identified the materials. AM identified and interpreted plant macrofossils from MG10.KT taught YSh the procedure to constrain event ages by OxCal and YSh constrained them. YSh led the writing of the text and preparation of the figures. All authors read and approved the final manuscript.

\section{Competing interests}

The authors declare that they have no competing interests.

\section{Publisher's Note}

Springer Nature remains neutral with regard to jurisdictional claims in published maps and institutional affiliations.

\section{Author details}

${ }^{1}$ Graduate School of Life and Environmental Sciences, University of Tsukuba, 1-1-1 Tennodai, Tsukuba, Ibaraki 305-8572, Japan. ${ }^{2}$ Faculty of Life and Environmental Sciences, University of Tsukuba, 1-1-1 Tennodai, Tsukuba, Ibaraki 305-8572, Japan. ${ }^{3}$ Geological Survey of Japan, National Institute of Advanced Industrial Science and Technology (AIST), 1-1-1-C7 Higashi, Tsukuba, Ibaraki 305-8567, Japan. ${ }^{4}$ Graduate School of Horticulture, Chiba University, 648 Matsudo, Matsudo, Chiba 271-8510, Japan. ${ }^{5}$ Department of Geology and Paleontology, National Museum of Nature and Science, 4-1-1 Amakubo, Tsukuba, Ibaraki 305-0005, Japan. 'Earthquake Research Institute, The University of Tokyo, 1-1-1 Yayoi, Bunkyo-ku, Tokyo 113-0032, Japan. ${ }^{7}$ School of Biological, Earth and Environmental Sciences, UNSW Sydney, Sydney, NSW 2052, Australia.

Received: 22 November 2018 Accepted: 13 March 2019

Published online: 02 April 2019

\section{References}

Abe F, Sugeno Y, Chigama A (1990) Estimation of the height of the Sanriku Jogan 11 earthquake-tsunami (A.D. 869) in the Sendai Plain. J Seismol Soc Japan 43:513-525 https://doi.org/10.4294/zisin1948.43.4_513 (in Japanese with English abstract). 2nd ser

Abe T, Goto K, Sugawara D (2012) Relationship between the maximum extent of tsunami sand and the inundation limit of the 2011 Tohoku-oki tsunami on the Sendai plain, Japan. Sediment Geol 282:142-150 https://doi.org/10.1016/j. sedgeo.2012.05.004

Ariake Bay Research Group (1965) Quaternary system of the Ariake and the Shiranui Bay areas, with special reference to the Ariake soft clay. Earth Sci 11: 1-86 (in Japanese)

Atwater BF, Hemphill-Haley E (1997) Recurrence intervals for great earthquakes of the past 3,500 years at northeastern Willapa Bay, Washington. United States Government Publishing Office, Washington D.C

Atwater BF, Musumi-Rokkaku S, Satake K, Tsuji Y, Ueda K, Yamaguchi DK (2005) The orphan tsunami of 1700-Japanese clues to a parent earthquake in North America. University of Washington Press, Seattle

Baba T, Okada T, Ashi J, Kanamatsu T (2017) A possible source model of the 1512 Eisho tsunami described in an ancient document, Abstract HDS12-10 presented at the JpGU-AGU Joint Meeting 2017, Makuhari, Japan, pp 20-25 May 2017. https://confit.atlas.jp/guide/event/jpguagu2017/subject/HDS12-10/ detail. Accessed 10 Sept 2018

Bronk Ramsey C (2017) Methods for summarizing radiocarbon datasets. Radiocarbon 59:1809-1833. https://org/https://doi.org/10.1017/RDC.2017.108

Central Meteorological Observatory (1947) Showa 21 nen 12 gatsu 21 nichi Nankaido dai jishin chosa gaiho (survey overview of the December 21, Showa 21 Nankaido earthquake). Central Meteorological Observatory, Tokyo (in Japanese)

Chiba T, Sawai Y (2014) Reexamination and updating of diatom species for paleoenvironmental reconstructions. Diatom 30:17-30 https://doi.org/10. 11464/diatom.30.17 (in Japanese with English abstract) 
Choowong M, Murakoshi N, Hisada K, Charoentitirat T, Charusiri P, Phantuwongraj S, Wongkok P, Choowong A, Subsayjun R, Chutakositkanon V, Jankaew K, Kanjanapayont P (2008a) Flow conditions of the 2004 Indian Ocean tsunami in Thailand, inferred from capping bedforms and sedimentary structures. Terra Nova 20:141-149 https://doi.org/10.1111/j.1365-3121.2008.00799.x

Choowong M, Murakoshi N, Hisada K, Charusiri P, Charoentitirat T, Chutakositkanon V, Jankaew K, Kanjanapayont P, Phantuwongraj S (2008b) 2004 Indian Ocean tsunami inflow and outflow at Phuket, Thailand. Mar Geol 248:179-192 https:/doi. org/10.1016/j.margeo.2007.10.011

Editing Committee of the History of Anan City (1995) Anan shishi. Anan City, Anan City (in Japanese)

Editing Committee of the History of Hiwasa Town (1984) Hiwasa choshi. Hiwasa Town, Hiwasa Town (in Japanese)

Editing Committee of the History of Mugi Town (1976) Mugi choshi. Mugi Town, Mugi Town (in Japanese)

Editing Committee of the History of Tokushima Prefecture (1963) Tokushima Kenshi. Tokushima Prefecture, Tokushima City (in Japanese)

Fujino S, Kimura H, Komatsubara J, Matsumoto D, Namegaya Y, Sawai Y, Shishikura M (2018) Stratigraphic evidence of historical and prehistoric tsunamis on the Pacific coast of Central Japan: implications for the variable recurrence of tsunamis in the Nankai trough. Quat Sci Rev 201:147-161 https://doi.org/10.1016/j.quascirev.2018. 09.026

Garrett E, Fujiwara O, Garrett P, Heyvaert VMA, Shihikura M, Yokoyama Y, HubertFerrari A, Brückner H, Nakamura A, De Batist M, the QuakeRecNankai team (2016) A systematic review of geological evidence for Holocene earthquakes and tsunamis along the Nankai-Suruga trough, Japan. Earth-Sci Rev 159:337357 https://doi.org/10.1016/j.earscirev.2016.06.011

Goff J, McFadgen BG, Chagué-Goff C (2004) Sedimentary differences between the 2002 Easter storm and the 15th-century Okoropunga tsunami, southeastern North Island, New Zealand. Mar Geol 204:235-250 https://doi.org/10.1016/S00253227(03)00352-9

Hamilton S, Shennan I (2005) Late Holocene relative sea-level changes and the earthquake deformation cycle around upper cook inlet, Alaska. Quat Sci Rev 24:1479-1498 https://doi.org/10.1016/j.quascirev.2004.11.003

Hemphill-Haley E (1996) Diatoms as an aid in identifying late-Holocene tsunami deposits. The Holocene 6:439-448 https://doi.org/10.1177/ 095968369600600406

Hirabayashi S, Yokoyama Y, Suzuki A, Miyairi Y (2017) Takahiro Aze short-term fluctuations in regional radiocarbon reservoir age recorded in coral skeletons from the Ryukyu Islands in the North-Western Pacific. J Quatern Res 32:1-6 https://doi.org/10.1002/jqs.2923

Hirose K, Gotoh T, Sato H, Yoshikawa S (2004) Diatoms in surface sediments from northeastern part of Osaka Bay, southwestern Japan. Diatom 20:229-240 https:// doi.org/10.11464/diatom1985.20.0_229

Ikehara K (1999) Recurrence interval of deep-sea turbidites and its importance for paleoseismicity analysis. J Sediment Soc Japan 49:13-21 https://doi.org/10. 4096/jssj1995.49.13 (in Japanese with English abstract)

Ishibashi K (2014) Nankai Trough kyodai jishin: Rekishi, Kagaku, Syakai (Nankai Trough great earthquake history, science and society). Iwanami Shoten, Tokyo (in Japanese)

Jankaew K, Atwater BF, Sawai Y, Choowong M, Charoentitirat T, Martin ME, Prendergast A (2008) Medieval forewarning of the 2004 Indian Ocean tsunami in Thailand. Nature 455:1228-1231

Joh G (2013) Species diversity of the old genus Navicula Bory (Bacillariophyta) on intertidal sand-flats in the Nakdong River estuary, Korea. J Ecol and Environ 36:371-390 https://doi.org/10.5141/ecoenv.2013.371

Kobayasi H, Idei M, Mayama S, Nagumo T, Osada K (2006) H. Kobayasi's atlas of Japanese diatoms based on electron microscopy 1. Uchida Rokakuho, Tokyo (in Japanese)

Kosugi M (1988) Classification of living diatom assemblages as the indicator of environments, and its application to reconstruction of paleoenvironments. The Quaternary Research (Daiyonki-Kenkyu) 27:1-20 https://doi.org/10.4116/ jaqua.27.1 (in Japanese with English abstract)

Krammer K, Lange-Bertalot H (1986) Süßwasserflora von Mitteleuropa. Bacillariophyceae 1. Teil: Naviculaceae. Gustav Fischer Verlag, Stuttgart

Kumon F (1981) Shimanto Supergroup in the southern part of Tokushima Prefecture, Southwest Japan. J Geol Soc Japan 87:277-295 https://doi.org/10. 5575/geosoc.87.277 (in Japanese with English abstract). pl 1.

Levkov Z (2009) Amphora sensu lato. In: Lange-Bertalot H (ed) Diatoms of Europe: diatoms of the European inland waters and comparable habitats. Volume, vol 5. A. R. G. Gantner Verlag K. G, Ruggell
Lienkaemper JJ, Bronk Ramsey C (2009) OxCal: versatile tool for developing paleoearthquake chronologies_a primer. Seismol Res Lett 89(3):431-434 https://doi.org/10.1785/gssrl.80.3.431

Matsumoto D, Sawai Y, Tanigawa K, Fujiwara O, Namegaya Y, Shishikura M, Kagohara K, Kimura H (2016) Tsunami deposit associated with the 2011 Tohoku-oki tsunami in the Hasunuma site of the Kujukuri coastal plain, Japan. Island Arc 25:369-385 https://doi.org/10.1111/iar.12161

Matsushita M, Sato H, Suzuki S, Yukumoto K, Momohara A, Ueda Y, Katoh S, Maeda $Y$ (2004) Paleoenvironmental analyses of the buried peat deposit during the mid-Holocene at the Desaki coast in Tamano City, Okayama prefecture, Western Japan. Okayama University Earth Science Reports 11: 39-47 (in Japanese with English abstract)

Minoura K, Imamura F, Sugawara D, Kono Y, Iwashita T (2001) The 869 Jogan tsunami deposit and recurrence interval of large-scale tsunami on the Pacific coast of Northeast Japan. J Nat Disaster Sci 23:83-88

Minoura K, Nakaya S (1991) Traces of tsunami preserved in inter-tidal lacustrine and marsh deposits: some examples from Northeast Japan. J Geol 99:265$287 \mathrm{https}: / /$ doi.org/10.1086/629488

Monecke K, Finger W, Klarer D, Kongko W, McAdoo BG, Moore AL, Sudrajat SU (2008) A 1,000-year sediment record of tsunami recurrence in northern Sumatra. Nature 455:1232-1234

Morton RA, Gelfenbaum G, Jaffe BE (2007) Physical criteria for distinguishing sandy tsunami and storm deposits using modern examples. Sediment Geol 200:184-207 https://doi.org/10.1016/j.sedgeo.2007.01.003

Murakami H, Shimada T, Itoh S, Yamamoto N, Ishizuka J (1996) Reexamination of the heights of the 1605, 1707 and 1854 Nankai tsunamis along the coast of Shikoku Island. J Nat Disaster Sci 15:39-52 (in Japanese with English abstract)

Nagumo T (1995) Simple and safe cleaning methods for diatom samples. Diatom 10:88 https://doi.org/10.11464/diatom1985.10.0_88 (in Japanese)

Nagumo T, Kobayasi H (1990) The bleaching method for gently loosening and cleaning a single diatom frustule. Diatom 5:45-50 https://doi.org/10. 11464/diatom1985.5.0_45

Nakamura Y, Nishimura Y, Putra PS (2012) Local variation of inundation, sedimentary characteristics, and mineral assemblages of the 2011 Tohoku-oki tsunami on the Misawa coast, Aomori, Japan. Sediment Geol 282:216-227 https://doi.org/10.1016/j.sedgeo.2012.06.003

Nakata T, Shimazaki K (1997) Geo-slicer, a newly invented soil sampler, for highresolution active fault studies. J Geogr 106:59-69 https://doi.org/10.5026/ jgeography.106.59 (in Japanese with English abstract)

Nanayama F, Satake K, Furukawa R, Shimokawa K, Atwater BF, Shigeno K, Yamaki S (2003) Unusually large earthquakes inferred from tsunami deposits along the Kuril trench. Nature 424:660-663

Nanayama F, Shigeno K (2006) Inflow and outflow facies from the 1993 tsunami in Southwest Hokkaido. Sediment Geol 187:139-158 https://doi.org/10.1016/j. sedgeo.2005.12.024

Naruse H, Fujino S, Suphawajruksakul A, Jarupongsakul T (2010) Features and formation processes of multiple deposition layers from the 2004 Indian Ocean tsunami at ban Nam Kem, southern Thailand. Island Arc 19:399-411 https:/doi. org/10.1111/j.1440-1738.2010.00732.x

Nelson AR, Sawai Y, Jennings AE, Bradley A, Gerson L, Sherrod BL, Sabean J, Horton BP (2008) Great-earthquake paleogeodesy and tsunamis of the past 2000 years at Alsea Bay, Central Oregon coast, USA. Quat Sci Rev 27:747-768 https://doi.org/10.1016/j.quascirev.2008.01.001

Okamura M. Matsuoka H (2012) Tsunami taisekibutsu kara wakaru Nankai jishin no kurikaeshi (Nankai earthquake recurrences from tsunami sediment). Kagaku 82:182-191 (in Japanese)

Okamura M, Matsuoka H, Tsukuda E, Tsuji Y (2000) Kogan kosho taisekibutsu ni yoru kako ichiman nen no chikaku hendou to rekishi tsunami monitoring (tectonic movements of recent 10000 years and observations of historical tsunamis based on coastal lake deposits). Chikyu Mon 28:162-168 (in Japanese)

Onishi CT, Kimura G (1995) Change in fabric of melange in the Shimanto Belt, Japan: change in relative convergence? Tectonics 14:1273-1289 https://doi. org/10.1029/95TC01929

Patrick RM, Reimer CW (1966) The diatoms of the United States exclusive of Alaska and Hawaii, vol 1. Academy of Natural Sciences of Philadelphia, Philadelphia

Patrick RM, Reimer CW (1975) The diatoms of the United States exclusive of Alaska and Hawaii, vol 2. Academy of Natural Sciences of Philadelphia, Philadelphia 
Reimer PJ, Bard E, Bayliss A, Beck JW, Blackwell PG, Ramsey CB, Buck CE, Cheng H, Edwards RL, Friedrich M, Grootes PM, Guilderson TP, Haflidason H, Hajdas I, Hatté C, Heaton TJ, Hoffmann DL, Hogg AG, Hughen KA, Kaiser KF, Kromer B, Manning SW, Niu M, Reimer RW, Richards DA, Scott EM, Southon JR, Staff RA CSM T, JVD PI (2013) Cal13 and Marine13 radiocarbon age calibration curves 0-50,000 years cal BP. Radiocarbon 55:1869-1887 https://doi.org/10.2458/ azu_js_rc.55.16947

Sabbe K, Vyverman W, Muylaert K (1999) New and little-known Fallacia species (Bacillariophyta) from brackish and marine intertidal sandy sediments in Northwest Europe and North America. Phycologia 38:8-22 https://doi.org/10. 2216/i0031-8884-38-1-8.1

Sakaguchi A, Kimura G, Strasser M, Screaton EJ, Curewitz D, Murayama M (2011) Episodic seafloor mud brecciation due to great subduction zone earthquakes. Geology 39:919-922 https://doi.org/10.1130/G32043.1

Sakaguchi Y, Kashima K, Matsubara A (1985) Holocene marine deposits in Hokkaido and their sedimentary environments. Bull Dept Geogr Univ Tokyo $17: 1-17$

Sangawa A (2007) Jishin no nihonshi (earthquakes in Japanese history). Chuokoron-shinsha, Tokyo (in Japanese)

Sawai Y, Fujii Y, Fujiwara O, Kamataki T, Komatsubara J, Okamura Y, Satake K, Shishikura M (2008) Marine incursions of the past 1500 years and evidence of tsunamis at Suijin-numa, a coastal lake facing the Japan trench. The Holocene 18:517-528 https://doi.org/10.1177/0959683608089206

Sawai Y, Jankaew K, Martin ME, Prendergast A, Choowong M, Charoentitirat T (2009b) Diatom assemblages in tsunami deposits associated with the 2004 Indian Ocean tsunami at Phra Thong Island, Thailand. Mar Micropaleontol 77: 70-79 https://doi.org/10.1016/j.marmicro.2009.07.003

Sawai Y, Kamataki T, Shishikura M, Nasu H, Okamura Y, Satake K, Thomson KH, Matsumoto D, Fujii Y, Komatsubara J, Aung TT (2009a) Aperiodic recurrence of geologically recorded tsunamis during the past 5500 years in eastern Hokkaido, Japan. J Geophys Res 114:B01319 https://doi.org/10.1029/ 2007JB005503

Sawai Y, Namegaya Y, Okamura Y, Satake K, Shishikura M (2012) Challenges of anticipating the 2011 Tohoku earthquake and tsunami using coastal geology. Geophys Res Lett 39:L21309 https://doi.org/10.1029/2012GL053692

Sawai Y, Satake K, Kamataki T, Nasu H, Shishikura M, Atwater BF, Horton BP, Kelsey HM, Nagumo T, Yamaguchi M (2004) Transient uplift after a 17thcentury earthquake along the Kuril subduction zone. Science 306:1918-1920 https://doi.org/10.1126/science.1104895

Shennan I, Hamilton S (2006) Coseismic and pre-seismic subsidence associated with great earthquakes in Alaska. Quat Sci Rev 25:1-8 https://doi.org/10. 1016/j.quascirev.2005.09.002

Shibata T, Orihashi Y, Kimura G, Hashimoto Y (2008) Underplating of mélange evidenced by the depositional ages: U-Pb dating of zircons from the Shimanto accretionary complex, Southwest Japan. Island Arc 17:376-393 https://doi.org/10.1111/j.1440-1738.2008.00626.x

Shishikura M, Echigo T, Heitaro K (2007) Marine reservoir correction for the Pacific coast of Central Japan using 14C ages of marine mollusks uplifted during historical earthquakes. Quat Res 67:286-291 https://doi.org/10.1016/j.yqres. 2006.09.003

Shishikura M, Echigo T, Maemoku H, Ishiyama T (2008) Height and ages of uplifted sessile assemblage distributed along the southern coast of the Kii peninsula, south-central Japan: reconstruction of multi-segment earthquake history along the Nankai Trough. Ann Rep Active Fault and Paleoearthquake Res 8:267-280 (in Japanese with English abstract)

Suyari K, Yamasaki T (1987) Boundary between the north and South Shimanto subbelts in Tokushima Prefecture. J Sci Coll Gen Educ Univ Tokushima 20:3746 Pls 1-9 (in Japanese)

Szczuciński W, Kokociński M, Rzeszewski M, Chagué-Goff C, Cachão M, Goto K, Sugawara D (2012) Sediment sources and sedimentation processes of 2011 Tohoku-oki tsunami deposits on the Sendai plain, Japan: insights from diatoms, nannoliths and grain size distribution. Sediment Geol 282:40-56 https://doi.org/10.1016/j.sedgeo.2012.07.019

Takashimizu Y, Urabe A, Suzuki K, Sato Y (2012) Deposition by the 2011 Tohoku-oki tsunami on coastal lowland controlled by beach ridges near Sendai, Japan. Sediment Geol 282:124-141 https://doi.org/10.1016/j. sedgeo.2012.07.004

Takeuchi Y, Sassa T, Kawaguchi S, Ogasawara M, Yoneyama K, Konnai M (1995) Stimulation of germination of Monochoria vaginalis seeds by seed coat puncture and cotylenins. J Weed Sci and Technol 40:221-224 https://doi.org/ 10.3719/weed.40.221
Tanabe S, Hori K, Momohara A, Nakashima R (2016) Verification of the "Yayoi regression" in the Tonegawa Lowland, central Japan. J Geol Soc Japan 122: 135-153 (in Japanese with English abstract)

Tanigawa K, Shishikura M, Fujiwara O, Namegaya Y, Matsumoto D (2018) Mid-to late-Holocene marine inundations inferred from coastal deposits facing the Nankai Trough in Nankoku, Kochi Prefecture, southern Japan. The Holocene 28:867-878 https://doi.org/10.1177/0959683617752837

Tanioka Y, Satake K (2001) Coseismic slip distribution of the 1946 Nankai earthquake and aseismic slips caused by the earthquake. Earth Planets and Space 53:235-241 https://doi.org/10.1186/BF03352380

The Headquarters for Earthquake Research Promotion (2001) Evaluations of occurrence potentials or subduction-zone earthquakes. https://www.jishin.go. jp/main/chousa/kaikou_pdf/nankai.pdf Accessed 1 Feb 2019 (in Japanese)

The Headquarters for Earthquake Research Promotion (2013) Evaluations of occurrence potentials or subduction-zone earthquakes. https://www.jishin.go. jp/main/chousa/kaikou_pdf/nankai_2.pdf Accessed 14 Sept 2018 (in Japanese)

Tuttle M, Ruffman A, Anderson T, Jeter H (2004) Distinguishing tsunami from storm deposits in eastern North America: the 1929 grand banks tsunami versus the 1991 Halloween storm. Seismol Res Lett 75:117-131 https://doi. org/10.1785/gssrl.75.1.117

Umitsu M (1991) Holocene sea-level changes and coastal evolution in Japan. Holocene sea-level changes and coastal evolution in Japan, vol 30, pp 187196 https://doi.org/10.4116/jaqua.30.187

Usami T, Ishii H, Imamura T, Takemura M, Matsumura R (2013) Materials for comprehensive list of destructive earthquakes in Japan, 599-2012. University of Tokyo Press, Tokyo (in Japanese)

Witkowski A, Lange-Bertalot H, Metzeltin D (2000) Diatom flora of marine coasts I, Iconographia Diatomologica 7. A.R.G. Gantner Verlag K. G, Ruggell

Yamada M, Fujino S (2013) Sedimentary characteristics of the onshore tsunami deposits formed by the 2011Tohoku-oki tsunami in coastal lowlands, Ibaraki and Chiba prefectures. J Sediment Soc Japan 72:13-25 https://doi.org/10. 4096/jssj.72.13 (in Japanese with English abstract)

Yamaguchi A, Shibata T, Ujiie K, Kimura G (2009) Deformation and fluid flow in seismogenic subduction zone: the Mugi Mélange in the Shimanto Belt. J Geol Soc Japan 115(Supplement):21-36 https://doi.org/10.5575/geosoc.115. S21 (in Japanese)

Yoneda M, Kitagawa H, Plicht JVD, Uchida M, Tanaka A, Uehiro T, Shibata Y, Morita M, Ohno T (2000) Pre-bomb marine reservoir ages in the western North Pacific: preliminary result on Kyoto University collection. Nucl Instr Meth Phys Res B 172:377-381 https://doi.org/10.1016/S0168-583X(00)00361-X

Yoneda M, Uno H, Shibata Y, Suzuki R, Kumamoto Y, Yoshida K, Sasaki T, Suzuki A, Kawahata H (2007) Radiocarbon marine reservoir ages in the western Pacific estimated by pre-bomb molluscan shells. Nucl Instr Meth Phys Res B 259:432-437 https://doi.org/10.1016/j.nimb.2007.01.184

\section{Submit your manuscript to a SpringerOpen ${ }^{\circ}$ journal and benefit from:}

- Convenient online submission

- Rigorous peer review

- Open access: articles freely available online

- High visibility within the field

- Retaining the copyright to your article

Submit your next manuscript at $>$ springeropen.com 